\title{
Effects of Academic Stress on Sports Participation of Students Especially at Government Colleges Punjab, Pakistan
}

\author{
Kashif Ali*, Salahuddin Khan, Afshan Jabeen and Jaffar Jug \\ Department of Sports, University of Sargodha, Pakistan
}

Submission: January 17, 2018; Published: January 26, 2018

*Corresponding author: Kashif Ali, Department of Sports, University of Sargodha, Pakistan, Email: kash46i@gmail.com

\begin{abstract}
Academic stress means the load of homework, assignments, presentations, consecutive lectures, competition of high grades in connection to participate in sports activities. The main objective of this study was to highlight the academic constraints and their effect on student's participation in sports activities in government college of PUNJAB. The population of this study comprised the lecturer physical education, principals, directorates of colleges and male students (16-20) of government degree colleges in Punjab. The researcher used multi stage sampling technique in this study. There are 36 districts in Punjab, the researcher choose only 15 districts in first stage from whole population through convenient sampling technique. In second stage from each district 4 boys degree colleges selected through simple random sampling technique and in third stage from each college the researcher choose one physical education lecturer, principal and 20 male students (16-20) years, Directorates of colleges 15 from selected districts so the total number of sample from one district was 89 and from 15 districts it was 1335. Likert type scale was used for the purpose of data collection. Regression was used for the purpose of data analysis. After completion the above process it was concluded that there is a significant effect of academic stress upon student's participation in sports activities at college level.
\end{abstract}

\section{Introduction}

Vuori [1] argued that regular exercise and physical activities remain a sound behavior in the promotion of health, preventing or postponing prevalence of neuromuscular problems, such as shoulder pain, neck pain, low back pain, and to stop the risk of developing heart diseases, diabetes, colon cancers, obesity, osteoporosis, and hypertension. Kilpatick et al. [2] stated that participation in sports has also been shown to have good effects on mental well-being, psychological enhancement, physical health and stress reactivity. Piko, Keresztes [3] argued that in this computerized age most of the people use only finger tips to push on and off the button to perform different types of work. So due to lack of physical or mental activities the peoples become lazy, and face different types of diseases such as tension, worry and diabetes etc. In order to avoid all these health risks and to keep the body fit, we need to participate in different kinds of sports and physical activities. Participation in sports activities helps in the physical development of children. The children who regularly participate in sports activities can easily express themselves. Physically fit children express themselves easily than those children who are not physically fit and not participate in sports and physical activities.

Sports also focus on recreation by providing a variety of programs like, hiking, Girl Guide, scouting and mountaineering. These programs are proven good sources for catharsis because involving in recreational programs one can remove his / her anxieties, depression and worries. By removing these negative factors, an individual can spend a happy and healthy life. Ongong et al. [4] found that sports and recreational activities are the best source of spending leisure time. Furthermore non participation in sports may cause of immoral activities such as use of drugs and illegal sexual contact with others. Sports and games are considered main factors about developing good relations between different countries in the world. Sports are considered good source for people of different regions and countries to understand each other, to make good relations as well as to acquire knowledge about the culture, geography and customs of different regions and countries. So by taking part in sports, individuals can develop sound relations among themselves and can remove the conflicts and misunderstandings among themselves.

Sports helps in the promotion of Active life style, active life style means work efficiently and actively in all the fields of life. To spend active life, there are many sports programs for every age group. By participating in these programs individuals can spend active life and can make progress in every profession of life. History shows that countries which lead in sorts lead in every fields of life. Onifade [5] noted that sports and games has become compulsory part of this society with its effects being felt in all parts of National life and has also become a sign of unity 
which governments use to legalize themselves. The present research study conducted to explore the influence of academic stress on sports participation among the government college students in the province of PUNJAB.

\section{Methods and Materials}

\section{Population of the Study}

The population of this study comprised the lecturer physical education, principals, directorates of colleges and male students (16-20) of government degree colleges in Punjab.

\section{Sample and Sample Size}

The researcher used multi stage sampling technique in this study. There are 36 districts in Punjab, the researcher choose only 15 districts in first stage from whole population through convenient sampling technique. In second stage from each district 4 boys degree colleges selected through simple random sampling technique and in third stage from each college the researcher choose one physical education lecturer, principal and 20 male students (16-20) years, Directorates of colleges 15 from selected districts so the total number of sample from one district

Results

Table 1. was 89 and from 15 districts it was 1335 .

\section{Instrument}

The researcher developed a questionnaire and used for the data collection. The questionnaire was consisting of 10 questions. The questionnaire was put to the 20 experts from Gomal University to establish the reliability. The reliability of this questionnaire was found to be 0.86 . This questionnaire was a Likert type consisting of five options (Strongly agree, agree undecided, disagree and strongly disagree).

\section{Administration of Instrument}

Questionnaire is distributed to respondents. After given time, the filled questionnaires were collected from the respondents. The researcher tries his best to explain the questions to the respondents during the distribution of questionnaire copies.

\section{Data Analysis}

a) The obtained data were tabulated and analyzed by using SPSS (version 24).

b) Regression analysis was applied on the obtained data reach at the final results.

\begin{tabular}{|c|c|c|c|c|}
\hline \multicolumn{5}{|c|}{ Model Summary $^{\mathbf{b}}$} \\
\hline Model & R & R Square & Adjusted R Square & Std. Error of the Estimate \\
\hline 1 & $.791^{\text {a }}$ & .626 & .626 & .64695 \\
\hline \multicolumn{5}{|r|}{ a. Predictors: (Constant), Academic Stress } \\
\hline
\end{tabular}

Table 2: Effect of academic stress on sports.

\begin{tabular}{|c|c|c|c|c|c|c|}
\hline \multicolumn{7}{|c|}{ Coefficients $^{\mathrm{a}}$} \\
\hline \multirow{2}{*}{ Model } & \multicolumn{2}{|c|}{ Unstandardized Coefficients } & \multirow{2}{*}{\multicolumn{2}{|c|}{$\begin{array}{c}\text { Standardized Coefficients } \\
\text { Beta }\end{array}$}} & \multirow[t]{2}{*}{$\mathbf{T}$} & \multirow[t]{2}{*}{ Sig. } \\
\hline & B & Std. Error & & & & \\
\hline \multirow{2}{*}{1} & (Constant) & .966 & .046 & & 21.042 & .000 \\
\hline & Academic Stress & .709 & .015 & .791 & 47.225 & .000 \\
\hline
\end{tabular}

Above Tables 1 \& 2 shows the effect of academic stress on sports. The R square is 0.626 which means that $62 \%$ effect on sports is due academic stress. The B is $0.709(\mathrm{p}=0.000)$ which means total 1 unit increase in parent and student barriers will cause 0.709 unit overall increase. After the above all process the result shows that academic stress makes Hurdles in way of sports participation among the government college students. The overall effect of academic stress was found $62 \%$ upon sports participation among the college students.

\section{Discussion}

The study was conducted to assess the effect of academic stress on male student's participation in sports activities at degree colleges for boys in Punjab, Pakistan. The study revealed that there is significant effect of academic stress on male student's participation in sports activities. Unfortunately, during college timing there is no chance to take part in sports due to consecutive lectures. The burden of Assignment and examination take most of the student's time for preparation at colleges, in the preparation of test and assignment the student do not have time to participate in sports activities. Lecturers also do not like the participation of students in sports activities, they think that sports activities are only leisure time activities and wastage of time and students cannot make balance between academic activities and sports activities. Most of the students only conscious about their academic activities and just focused on their home works and lectures. In this connection, Wilson [6] carried out a study entitled Comparing Sources of Stress in College Student Athletes and Non-Athletes. The 362 volunteer participants were take part in this study; the researcher found that athletes differed in a variety of ways from their non-athlete 
counterparts. The student's athletes report more academic stress then non-athletes students. Similarly, Pritchard, Wilson et al. [7] found that athletes may experience even greater levels of stress due to the dual demands of athletics and academics placed on them during their freshman year.

\section{Conclusion}

On the basis of data analysis and findings of the study the following conclusions were drawn by the researcher. The researcher found that academic stress significantly affect the male student's participation in sports at government degree colleges for boys in Punjab. The overall effect of academic stress was found $62 \%$ upon sports participation among male students at college level.

\section{References}

1. Vuori I (1995) Exercise and physical health: Musculo skeletal and functional capabilities. Research Quarterly for Exercise and Sport 66(4): 276-285.

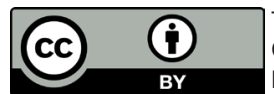

his work is licensed under Creative Commons Attribution 4.0 Licens

DOI: 10.19080/JPFMTS.2018.01.555569
2. Kilpatick M, Hebert E, Bartholomew J (2005) College Students' Motivation for Physical Activity: Differentiating Men's and Women's Motives for Sport Participation and Exercise. Journal of American College Health 54(2): 87-94.

3. Piko B, Keresztes N (2006) Physical activity, psychological health, and life goals among youth. Journal of community health 31(2): 136-145.

4. Ongong, Okwara, Okello (2010) Sports and secondary school education in Kenya. International research journals educational research 1(11): 609-617.

5. Onifade A (2001) Sport and society. In CO Udoh (Edn). Issues in human kinetics heath promotion and education. Ibadan: Chris-Rose ventures pp. 130-140.

6. Wilson G (2005) Comparing Sources of Stress in College Student Athletes and Non-Athletes. Sports psychology 7(1): 1-8.

7. Pritchard ME, Wilson G, Yamnitz B (2004) What predicts adjustment among college students? A Longitudinal Panel Study. J Am Coll Health 56(1): 15-21.

\section{Your next submission with Juniper Publishers will reach you the below assets}

- Quality Editorial service

- Swift Peer Review

- Reprints availability

- E-prints Service

- Manuscript Podcast for convenient understanding

- Global attainment for your research

- Manuscript accessibility in different formats

( Pdf, E-pub, Full Text, Audio)

- Unceasing customer service

\section{Track the below URL for one-step submission}

https://juniperpublishers.com/online-submission.php 